\title{
Análise comparativa de feiras orgânicas e convencionais, no município de Campinas (SP), como mecanismo de fomento à agricultura familiar, à conservação da agrobiodiversidade e à segurança alimentar
}

\author{
Mohamed Ezz EI Din Mostafa Habib (PQ), Giovanna Garcia Fagundes (PG), Vanessa Ayumi Ueno (IC)
}

\begin{abstract}
Resumo
Este projeto comparou feiras orgânicas e convencionais de Campinas - SP. Constataram-se diferenças no perfil dos feirantes: os orgânicos são majoritariamente agricultores familiares que comercializam em circuitos curtos e os convencionais comercializam em circuitos longos. Não se observou insegurança alimentar nos grupos. Os preços dos orgânicos foram em média $7,3 \%$ mais caros. $E$ as feiras convencionais apresentaram maior variedade de produtos $(n=184)$ do que as orgânicas $(n=128)$.
\end{abstract}

Palavras Chave: Agroecologia, Circuitos curtos, Agricultura Familiar.

\section{Introducão}

As feiras livres têm um papel bastante importante como estratégia de desenvolvimento socioeconômico. Estudos indicam que quando estes espaços privilegiam os circuitos curtos de comercialização, especialmente no caso de venda direta, também tendem a potencializar a agricultura familiar de base ecológica, reaproximando agricultores e consumidores ${ }^{1}$. Diante deste contexto, 0 presente projeto teve como objetivo analisar comparativamente feiras orgânicas e convencionais, em Campinas (SP) buscando caracterizar o perfil dos feirantes, relação com a agricultura familiar, circuitos de comercialização, preços dos produtos, gargalos para a sua expansão e aspectos relacionados à presença da agrobiodiversidade e à segurança alimentar dos feirantes.

\section{Resultados e Discussão}

Através de entrevistas semi-estruturadas foi possível constatar diferenças no perfil dos feirantes. Enquanto os orgânicos são majoritariamente agricultores familiares que comercializam em circuitos curtos, os convencionais comercializam em circuitos longos, mediados pela CEASA. Em termos de preços, os orgânicos foram em média 7,3\% mais caros que os convencionais, sendo as maiores diferenças observadas nos grupos de frutas e legumes. Para verduras, raízes e tubérculos o preço médio dos orgânicos foi inferior. Os problemas para a expansão das feiras convergem, sendo a falta de apoio da prefeitura e as deficiências de infraestrutura os itens mais frequentes. Em relação à agrobiodiversidade, as feiras convencionais apresentaram maior variedade de produtos comercializados $(n=184)$ do que as orgânicas $(n=$
128), possivelmente porque a aquisição junto ao CEASA amplia seu acesso a mercadorias. De modo geral, foram contabilizadas 23 famílias diferentes de frutas, 16 famílias de hortaliças e 9 de hortaliças folhosas. Por fim, aplicando a Escala Brasileira de Medida de Insegurança Alimentar ${ }^{2}$ observou-se que nenhum feirante sofre de insegurança alimentar.

\section{Conclusões}

As feiras apresentam grande potencial de fomento à agricultura familiar de base agroecológica no município de Campinas (SP) e podem gerar repercussões positivas na consolidação da produção orgânica e também em nível regional. No entanto, é necessário que o poder público municipal desenvolva mecanismos que facilitem este processo e viabilize as condições necessárias para as melhorias nos espaços já existentes e para a sua ampliação.

Agradecimentos

Ao CNPq - PIBIC e a Pró-Reitoria de Pesquisa da Unicamp, pelo apoio financeiro e institucional.

\footnotetext{
${ }^{1}$ DAROLT, R.M.; LAMINE, C.; BRANDEMBURG, A. A diversidade dos circuitos curtos de alimentos ecológicos: ensinamentos do caso brasileiro e francês. Agriculturas, v.10, n. 2, p.8-13, junho 2013.

${ }^{2}$ SEGALL-CORRÊA, A. M.; MARIN-LEON, L. A Segurança Alimentar no Brasil: Proposição e Uso da Escala Brasileira de Medida da Insegurança Alimentar (EBIA) de 2003 a 2009. Segurança Alimentar e Nutricional, Campinas, v. 16, n.2, p. 1-19, 2009.
} 